ELORE (ISSN 1456-3010), vol. 17 - 2/2010.

Julkaisija: Suomen Kansantietouden Tutkijain Seura ry.

[http://www.elore.fi/arkisto/2_10/leppalahti2_2_10.pdf]

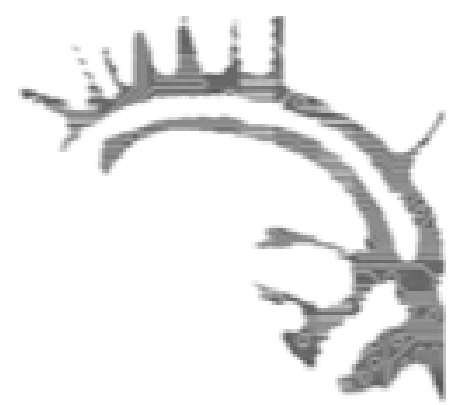

KirJA-ARVIO

\title{
TUTKIJA, TYTÖT JA TYKKÄÄMINEN
}

ANTTILA, ANNA 2009: Leikin asia. Näkökulmia varhaisnuorten romanttiseen seurustelukulttuuriin. Helsinki: Anna Anttila. [online] https:/loa.doria.filhandle/10024/46858. 290 sivua.

\section{Merja Leppälahti}

Anna Anttilan väitöskirjan tutkimuskohde on 1990-luvun varhaisnuorten romanttinen seurustelukulttuuri. Tutkija mainitsee, että varsinkin työn alkuvaiheissa hän sai kuulla kommentteja, joiden mukaan tällaista ilmiötä ei ole edes olemassa; väitöskirjassaan hän selkeästi osoittaa tämän väitteen vääräksi.

Artikkeliväitöskirjan viisi artikkelia ovat ilmestyneet vuosina 1996-2005 ja tutkimuksen aineisto on kerätty vuosina 1992-2000. Tämä tuo tutkimukseen mielenkiintoista ajallista perspektiiviä, kun varhaisemmin kerättyä aineistoa tarkastellaan nykypäivän tietämyksen valossa. Mahdollista muutosta lasten seurustelukulttuurissa ei kuitenkaan ole varsinaisesti erikseen tarkasteltu, sitä vain sivutaan johdantoluvussa. Tutkimusmenetelmänä on triangulaatio, johon tässä kuuluu monenlaisten aineistojen käyttäminen tarkoituksena saada tutkimusaiheesta mahdollisimman rikas ja monipuolinen kuva.

Tutkimuksessa käytetty aineisto on monipuolinen. Tutkija on itse kerännyt aineistoa haastattelemalla, havainnoimalla ja kirjallisin kyselyin, joita on organisoitu useissa kouluissa opettajien avustuksella. Yhden aineistopaketin muodostavat folkloristiikan ensimmäisen vuoden opiskelijoiden kokoamat haastattelut sekä kenttäpäiväkirjat ja esseet. Tässä aineistossa on myös videomateriaalia. Lisäksi tutkimusaineistona on käytetty kahden lasten kirjallisen keskustelupalstan kirjoituksia, ja nämä ovat kevään 2000 Yleisradion Uutisjutun Rakkausjuttu-keskustelupalsta internetissä sekä Koululainen-lehden 1998-vuosikerran yleisönosasto ja lehden verkkosivusto. Tutkimuksessa mukana olleet lapset olivat aineistonkeruuajankohtana koululaisia ensimmäiseltä luokalta lukiolaisiin. Myös internet- ja yleisönosastokirjoittajat ovat olleet ainakin oman ilmoituksensa mukaan korkeintaan 17-vuotiaita koululaisia. 
Merja Leppälahti: Tutkija, tytöt ja tykkääminen

\section{TuTKIJA SISKONA}

Anttila nimittää tutkimustaan siskoustutkimukseksi, joka ammentaa folkloristiikan relativistisen metodologian lisäksi tyttötutkimuksesta, naistutkimuksesta ja uudesta lapsuustutkimuksesta. Siskoustutkimus välttää hierarkiaa eikä rajaudu määrättyyn ikään, vaikka se kiinnittyy sekä sukupuoleen että sukupolveen.

Leikin asia on erityisesti folkloristinen tutkimus, jossa varhaisnuorten seurusteluun liittyviä ilmiöitä tarkastellaan osana varhaisnuorten omaa kulttuuria ja omia elämänkäytäntöjä. Tutkimuksen puitteissa olisi ollut mahdollista tarkastella myös perinteen ikäviä puolia, kuten nolaamista tai ulkopuolelle jättämistä, mutta nämä on tarkoituksella sivuutettu. Anttila sanoutuukin irti ongelmalähtöisestä tai normittavasta lapsuuden ja nuoruuden tutkimuksesta. Folkloristina hän näkee lastenkulttuurin ilmiöt kiinnostaviksi ja tärkeiksi tutkimuskohteiksi itsessään, ei pelkästään esimerkiksi aikuisuuteen valmistautumisen näkökulmasta.

Jokainen tutkija on joskus ollut lapsi ja siinä mielessä omaa henkilökohtaisia kokemuksia lapsuudesta sekä lapsena ja nuorena olemisesta. Tässä mielessä voisi kuvitella lapsi- tai nuorisotutkimuksen tekemisen olevan jossain määrin helpompaa kuin jonkin muun ryhmän tutkiminen. Todellisuudessa kuitenkin jo yhteiskunnassa tapahtuneet muutokset aiheuttavat sen, että monet lapsuuden kokemukset ovat nykyään kovin erilaisia kuin edes parikymmentä vuotta sitten. Leea Virtanen kirjoitti neljäkymmentä vuotta sitten: "Kuluneet vuodet eristävät aikuisen pihan salaisesta maailmasta tehokkaammin kuin pisinkään maantieteellinen matka." (Virtanen 1970, 14.) Anttila huomauttaakin, etteivät aikuisen omat, ehkä nostalgiset tai muuten värittyneet lapsuusmuistot ole paras mahdollinen lähestymistapa nykypäivän lasten tutkimisessa tai lasten elämän arvioimisessa. Edes oman lapsuutensa unelmiin ei kenelläkään ole enää aikuisena täydellisesti pääsyä, koska muistelija ei oikeastaan ole enää sama henkilö.

\section{RAKASTAA, EI RAKASTA...}

Anttilan väitöskirjatutkimus varhaisnuorten seurustelukulttuurista on lähtenyt liikkeelle koulutyttöjen rakkausennustuksia käsitelleestä opinnäytetyöstä. Tutkija sai kokoon lähes viisikymmentä erilaista keinoa ennustaa rakkausasioita. Hän on jakanut ennustukset neljään pääkategoriaan, joita ovat pelikorteista, kukista, kuvioista tai taulukoista ennustaminen sekä erilaiset laskutavat. Kukista ennustaminen tosin ilmeisesti näyttää keskittyvän juhannusyön kukkienpoimimiseen ja päivänkakkaroiden terälehtien laskemiseen (rakastaa-ei rakasta), joita kumpaakaan ei voi pitää erityisesti nimenomaan koululaisille ominaisina ennustusmuotoina.

Kiinnostavaa on ennustamisen vahva sukupuolittuneisuus, rakkausennustukset ovat nimenomaan tyttöjen perinnettä. Joskus ennustaminen pysyi pojilta niin piilossa, että vaikka luokan tytöt harrastivat innokkaasti rakkausennustuksia, saman luokan pojat saattoivat arvella, ettei sellaisia omalla luokalla tee kukaan. Joillakin luokilla 
pojatkin saattavat tietää ennustamisesta ja tuntea jopa joitakin ennustamisen tapoja, mutta poikien keskuudessa ei juuri rakkausennustuksia tehty. Anttilan aineistossa pojat joskus harmittelivat tyttöjen ennustamisintoa ja sitä, että joutuivat olemaan ennustusten kohteena, mutta eivät kuitenkaan mahtaneet tilanteelle mitään. Anttila nostaakin ennustamisen erääksi tyttöjen valtaistumisen tavaksi: ennustusten avulla tytöt saattoivat ainakin hetkellisesti ja leikillä ottaa itselleen aseman tulevaisuuden määrittelijänä ja rakentajana; tällaista asemaa ei alaikäisille eikä varsinkaan tytöille ole usein tarjolla.

Mielenkiintoista on, että koulutyttöjen rakkausennustusten toinen osapuoli on tavallisesti tuttu poika, usein luokkakaveri. Tyttöjen tulevaisuudenhaaveissa kuvailtu unelmapartneri ei kuitenkaan ole kouluympäristön ihastus, vaan toistaiseksi vielä tuntematon aikuinen mies. Hauska huomio on se, että vaikka tytöt kertovat tekevänsä ennustuksia huvikseen ja leikillä, huonoja tai muuten epämieluisia ennustuksia pyritään korjaamaan tai selittämään virheellisiksi.

Useat rakkausennustusten menetelmät ovat kansainvälisesti tunnettuja. Ennustustavat ovat levinneet kouluissa myös kirjallisuuden välityksellä. Tytöt ovat maininneet lukeneensa ennustuksista esimerkiksi Ulla Lipposen kokoelmasta Kilon poliisi (1987) ja Pirkko-Liisa Perttulan toimittamasta Rakkaus on ihana tauti (1993), jotka molemmat sisältävät myös rakkausennustuksia.

\section{Aletaaks oleen?}

Varhaisnuorten diskot nousivat keskustelunaiheiksi erityisesti 2000-luvun vaihteessa. Lapsuuteen liitetään usein ajatus huolettomuudesta ja viattomuudesta, jotka sitten myöhemmin, "oikeassa elämässä", menetetään. Kirjoittajan sanojen mukaan (aikuisten) diskot nähtiin "alkukantaisen villeinä ja jopa vaarallisina, avointa sukupuolisuutta tihkuvina luolina”. Tämän mukaisesti monien aikuisten mielikuvissa myös varhaisnuorten diskoihin liitettiin samat asiat: lapsille sopimaton musiikki seksuaalissävytteisine tai avoimen seksuaalisine sanoituksineen sekä tanssimiseen yleensäkin yhdistetyt siveettömyyden ja moraalittomuuden uhkat. Ennen kaikkea näiden diskojen nähtiin siis vetävän lapsia aivan liian aikaisin lapsuuden viattomuudesta aikuisten seksintäyteiseen maailmaan.

Anttila on kerännyt tutkimusaineistoa varhaisnuorten diskossa sekä henkilökohtaisesti että folkloristiikan kenttätyökurssilaisten avulla. Hänellä on sekä haastattelu- että videomateriaalia ja lisäksi omat ja opiskelijoiden havainnointimuistiinpanot. Artikkelissaan "Mulla se alko aina diskossa sillee jos tanssii sen kanssa" tutkija kuvaa sitä, mitä näissä diskoissa todella tapahtuu. Aineistovideoilla pikkutytöt eivät kulje meikattuina napapaidoissa, vaan sekä pojilla että tytöillä on hyvin samantyyppiset asut: löysät college-paidat tai isot, ruudulliset flanellipaidat. Pojat esiintyvät ja pelleilevät kuvaajille, tytöt käyttäytyvät hillitymmin. Suurin osa ajasta hengaillaan kuljeskellen ja jutellen, välillä joku tanssii lyhyen taidokkaan liikesarjan. Arvostelijoiden paheksumat "hitaat" tanssittiin vakavina ja puhumatta sen partnerin kanssa, 
joka on sattunut seisomaan lähettyvillä tanssin alkaessa. Diskoa voidaankin tämän tutkimuksen mukaan pitää lähinnä eräänä liikunnallisena harrastuksena tai lasten yhteisleikin muotona.

Lasten seurustelu "aletaaks oleen" -kysymyksineen on eräänlaista leikkiä, jossa aloitteen voi tehdä kumpi tahansa. Kimpassa oleminen ei ole kahdenkeskeinen asia, vaan julkinen sopimus sosiaalisine ja kollektiivisine seurauksineen. Tilanteeseen ei välttämättä sisälly mitään seurusteluksi miellettyjä asioita, ei edes välitunneilla juttelua, vaikka jotkut kimpassa olevat parit voivat joissain tilanteissa pitää kädestä ja jopa halailla tai pussailla. Ainakin tyttöjen puolella kimpassa olemiseen liittyy unelmia ja haaveita, vaikka tilanne kestäisi vain muutaman päivän. Anttilan aineistoissa näkyy kuitenkin vanha kaksinaismoralismi: pojat helposti rehvastelevat suhteillaan, kun taas tytöt varovat kiertopalkinnon mainetta.

\section{LEIKKIÄ VAKAVASTI}

Aikuisen tutkijan on hyvä muistaa, että lasten elämässä on ja on aina ollut asioita, joita ei mielellään kerrota aikuiselle. Tuttuus voisi luoda jo ennakolta valmiiksi luottamuksellisen suhteen, jossa pystytään kertomaan myös henkilökohtaisista asioista. Anttila kuitenkin arvelee, että tietyllä tavalla neutraaliksi koetun, tuntemattomuudesta tulevan ja sinne taas häviävän tutkijan voi olla helpompi saada kerätyksi arkaluonteista aineistoa kuin tutun henkilön, joka on läsnä arjessa myöhemminkin mahdollisesti nolostuttavine tietoineen. Anttila on saavuttanut tutkittaviensa luottamuksen suhtautumalla heihin arvostavasti ja myös lupaamalle heille intimiteettisuojan: lasten kirjoittamia tai kertomia asioita ei ole paljastettu opettajille, vanhemmille tai kavereille.

Mielenkiintoinen huomio on myös se, ettei varhaisnuorten "tykkääminen" ole enää nykyään aina sellainen häpeä kuin se on joskus ollut, vaan seurustelu ja "kimpassa oleminen" voivat kuulua asiaan ja olla suorastaan tavoiteltavia ja toivottavia olotiloja. Anttila toteaa kuitenkin, että aikuisten on edelleen toisinaan vaikea erottaa varhaisnuorten ystävyys- ja seurustelusuhteita toisistaan. Aikuiset helposti kiusoittelevat lapsia ihastuksista ja nimittävät esimerkiksi pojan tyttökavereita tuleviksi miniöiksi. Tämä on tutkijan mukaan ongelmallista siinä mielessä, että lapsille luodaan käsitystä, etteivät tyttö ja poika voi olla kavereita, hyviä ystäviä, vaan että tytön ja pojan suhde on aina seurustelusuhde.

Anttila suhtautuu lapsiin vakavasti. Hän ei tarkastele huvittuneesti hymyillen ylhäältäpäin lasten "pikku ihastumisia", vaan ottaa lasten tunteet tosissaan, sellaisina, kuin nämä itse kertovat. Varhaisnuorten "kimpassa oleminen" voi olla enemmän tyttöjenkeskeistä kuvitteluleikkiä kuin varsinaista seurustelua aikuisen mieltämässä mielessä. Anttila pohtii, miten paljon tämä tulkinta latistaa käsitystä tyttöjen tunteista: onko niin, että jos kysymyksessä on "pelkkä leikki", lasten tunteitakaan ei tarvitse pitää todellisina. Ihastuminen, rakastuminen, seurustelu ja hylätyksi tai petetyksi tuleminen voivat olla kuolemanvakavia asioita myös kymmenvuotiaalle, vaikka ne 
Merja Leppälahti: Tutkija, tytöt ja tykkääminen

tietenkin ovat aivan erilaisia kuin vaikka kaksikymmenvuotiaalle, nelikymppiselle tai seitsemänkymmentä täyttäneelle.

KirjallisuUs

LIPPONEN, ULLA (toim.) 1987: Kilon poliisi ja muita koululaisjuttuja. Helsinki: SKS. PERTTULA, PIRKKO-LIISA (toim.) 1993: Rakkaus on ihana tauti. Helsinki: Otava.

VIRTANEN, LEEA 1970: Antti pantti pakana. Helsinki: WSOY.

Filosofian lisensiaatti Merja Leppälahti on turkulainen folkloristi ja kriitikko. 